\title{
Studies
}

\section{ANCIENT HISTORY}

\section{GAME PHERSU: PRO ET CONTRA}

\begin{abstract}
Having examined the frescoes from Tarquinia: the Tomb of Augurs, the Tomb of the Pulcinella, and the Tomb of the Olympiads dated back to the sixth century $\mathrm{BCE}$ that depict scenes with a personage Phersu, the author deals with Etruscan inscriptions, data of the Antique tradition about origin of scenic and gladiatorial games, as well as a number of interpretations of these scenes to prove that the Etruscan ritual 'game Phersu' is a prototype of the Roman gladiatorial games and 'venatio'. Being a part of Etruscan funeral rite, the ritual game was a substitutive sacrifice that symbolised a fight of a human being against the demon of death Calu - an abductor of souls from the world of the living. The fight was supposed to be guided by an invisible and disguised power, being personified in the image of Phersu.
\end{abstract}

Keywords: Etruscan, gladiatorial games, Phersu, Rome, Etruria

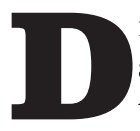

ifficulties experienced by interpreters of Etruscan inscriptions, as well as fragmentation of the ancient tradition about Etruscans, stimulates the search of new sources about the public life of the Etruscans. Iconographic sources, relics of Etruscan painting are being used more actively. The name "Phersu" appeared in Etruscology after discovery in Corneto (ancient Tarquinii, now Tarquinia) frescoes from the tombs of Pulcinella (530-520 B.C.) in 1872, and the Augurs (540-520 B.C.) in 1878. Mysterious character in mask, which has not received an unambiguous interpretation, is designated on the frescoes by the term persu (CIE 5328, 5335). If on the fresco of the first tomb it is depicted alone, whereas in the tomb of the Augurs Phersu is involved in the scene dog's hunting of a blindfolded man, while it is clear that by ropes Phersu tries to control the actions of the dog and limit the movement of the man (Fig. 1). Later it was discovered another painting in the

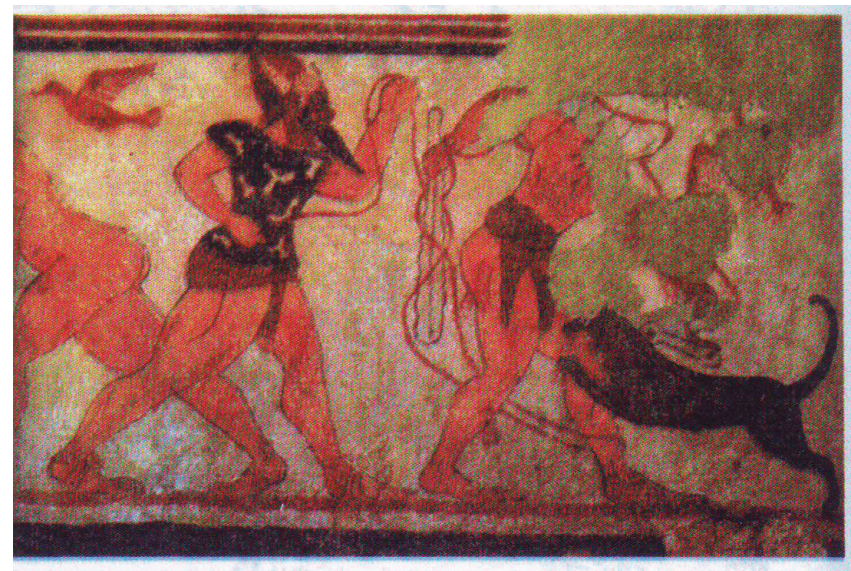

Fig. 1. Tomb of the Augurs, Tarquinia, ca. 520 BCE.

The Phersu Game. After Vsemirnaya istoriya: ellinisticheskiy i rimskiy periodyi / [A. N. Badak, I.E. Voynich, N.M. Volchek i dr.]; pod red. I. A. Alyabevoy. - Minsk: Harvest, M.: AST,1999. - P. 178, fig. 275.

\section{Andrew Yanko \\ Poltava National Technical Yuri \\ Kondratyuk University, \\ Department of History \\ andrewyanko@mail.ru}


tomb of Olympiad (525-520 B.C.) found in 1958, representing a poorly preserved scene similar to the image from the tomb of the Augurs ${ }^{1}$. Fresco from the tomb of the Cock in Tarquinia (400 BC) may also depicts Phersu².

The first researchers have already established connection of $\varphi$ ersu with the Latin word persona (mask, guise, face) and suggested their origin from Greek $\tau o ́$

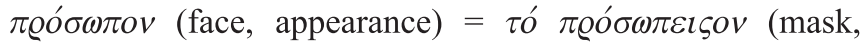

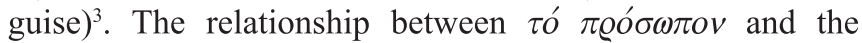

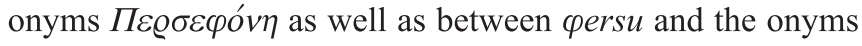
persipnai (CIE 5091) from the tomb of Golini in Orvieto and persipnei (CIE 5365) from the tomb of Orcus in Tarquinia $4^{\text {th }}$ century BC. ${ }^{4}$

Numerous hypotheses as an explanation of this obscure scene have been put forward. The earliest of them claims that Etruscans had game "Phersu", which became the forerunner

of the bestiaries fighting and gladiatorial games ${ }^{5}$. In particular, F. Altheim and E. Vetter assumed borrowing by Romans games from Campanian Etruscans brokered by Osk's Atel$\operatorname{lan}^{6}$. It was noticed that on the left wall of the tomb of the Augurs Phersu is depicted in comic form escaping, as well as later Roman goddess of the dead Mania, the mother of Lares, was depicted in comic form too?

J. Heurgon had not doubt that the mask that hides Phersu face is similar to the actors masks of popular farces, whose costumes formed the basis of characters of Italian "Commedia dell'Arte» ${ }^{8}$. He suggested that in Etruria, as in Campaign, their own comedy of masks existed, and the name Phersu derived from the name Fersifnay. 2000 years gap between the Etruscan Phersu and the closest to him by the external signs Harlequin ${ }^{9}$ prevents to construct the continuity of these images.

J. Burian and B. Mouhova called Phersu "bloody conductor" of a combat between man and $\operatorname{dog}^{10}$. An expert of gladiatorial games J. Ville suggested to consider the game "Phersu" as the scene «venatio» (hunting, baiting of animals on arena $)^{11}$. A. Hus believed that this is a simulation of a deadly battle for ritual purposes at the funeral ${ }^{12}$.

A. I. Nemirovsky initially believed that the name Phersu belonged to the person struggling with the dog, and the similarity of his name with the name of the Etruscan goddess of the underworld allowed to see in him the demon of death ${ }^{13}$. Later he corrected his mistake and called demon of underworld man in mask $^{14}$.

N. K. Timofeeva indicates the possibility of images parallel with Phersu and the fact that the last king of Lydian

\footnotetext{
POULSEN 1922, fig. 4-6; EMMANUEL-REBUFFAT 1983, Pl. II, fig. 1.

STEINGRÄBER 2006, 94.

DEEKE 1884, 47; SKUTSCH 1907, 789; BLUMENTHAL 1937, 1036; VETTER 1938, 2058.

4 BLUMENTHAL 1937, 1038; VETTER 1938, 2057-2058.

5 POULSEN 1922, 11-14

6 ALTHEIM 1938, 157-159; VETTER 1938, 2058. See also: (Horat. Sat. 1.5.52).

POULSEN 1922, 12; ALTHEIM 1938, 158-159

8 HEURGON 1961, 265-269.

9 But, see: familia Herlechini (Harlequin's people) (Order. Vit. 8.17) in 1091.

10 BURIAN/MOUCHOVA 1966, 143.

11 VILLE 1981, 1-8

12 HUS 1980, 215.

13 NEMIROVSKIY/HARSEKIN 1969, 128.

14 NEMIROVSKIY 1983, 225.
}

dynasty of the Heraclides was named $K \alpha v \delta \alpha u ́ d \varepsilon 5$ (choker of $\operatorname{dog})^{15}$. It should be noted that the direct relationship of the Lydians and the Etruscans is possible only in the messages of the ancient authors, beginning from Herodotus ${ }^{16}$, modern science is closer to Dionysius of Halicarnassus skepticism, who was claiming that neither the language nor there religious beliefs and laws of the Etruscans and the Lydians had nothing in common (Dion., Hal., Ant. Rom., I, 30, 1). Indeed, the Lydian language is the late Indo-European Hittite language, while the Etruscan is recognized as NonIndo-European ${ }^{17}$.

D. Emmanuel-Rebuffat noted some number of elements that did not consistent with the scene "venation" and preferred to see in this clash of a man with a dog representation of the myth about Hercules and Cerberus ${ }^{18}$.

J.-R. Jannot not linked this scene with later images of the Etruscan myth of Actaeon, torn by $\operatorname{dog} \mathrm{s}^{19}$. The researcher believed they were not mere "trivialization" of the Greek myths but magic replacing the archaic funerary ritual of man combat, representing the soul of the deceased in the afterlife, with a dog or a wolf of Hades. In another article he wrote that the word Phersu means the masked dancer and its role goes far beyond just the dog tamer from the tomb of Augurs ${ }^{20}$.

E. MacNamara gave three interpretations: the image of the myth of Hercules, the picture of human sacrifice, the scene of gladiatorial combat ${ }^{21}$. She did not put forward her own version, but did not join the stated ones.

N. M. Loseva and N. A. Sidorova saw in the picture the image of bloody game, dating back to the custom of human sacrifices ${ }^{22}$. A. E. Nagovitzin considered frescoes with Phersu as pageant of the Etruscan myth, where the demon Phersu was testing souls in the other world ${ }^{23}$. G. I. Sokolov saw not fleeing but dancing Phersu in the picture on the left wall of the tomb of the Augurs ${ }^{24}$.

J.-N. Robert saw in gestures of Phersu clownish parody on the games, played by masked actors, who were able to play the violence, giving to the games magic-religious character ${ }^{25}$.

F. Paolucci said that the game Phersu was connected with the burial ritual, and late gladiatorial games, but there was no confrontation between two armed men $^{26}$. Starting of munera themselves researcher deduces from Campania. His views are supported by researchers of gladiatura D. Slapek, V. A. Goroncharovsky and K. S. Nosov ${ }^{27}$. It should be noted that the game Phersu could be considered as a duel between two people: a tied up man with a cudgel and a masked man Phersu by name with a dog.

S. Stoddart's dictionary "The Etruscans" connects the ${ }_{15}$ TIMOFEEVA 1980, 99. See also Herodotus (1.7.2) that the real name of Candaules is Myrsilus (i.e. on-Hittite Mursili).

${ }_{16}$ Herod. 1.94; Strab. 5.2.2.C. 220; Vell. 1.1.4; Val. Max. 2.4.4; Tac. Ann. 4.55.3. BONFANTE 2002, 49, 225; FORSYTHE 2005, 26, 36; FORTSON IV 2011, 275; STODDART 2009, 108.

18 EMMANNUEL-REBUFFAT 1983, 427-431.

19 JANNOT 1984, 48-52.

JANNOT 1993, 320.

1 MACNAMARA 1987,172

2 LOSEVA/SIDOROVA 1988, 40.

NAGOVITSYIN 2000, 422.

SOKOLOV 2002, 74.

ROBERT 2004, 282.

PAOLUCCI 2003, 10-11.

SŁAPEK 1998, 116-117; GORONCHAROVSKIY 2009, 11-12; NOSOV 2010,14 
image on the mural with Phersu with a theater and games ${ }^{28}$. A. Avramidou compares the Phersu picture and the image on the Apulian calyx crater $340-330$ 's. BC. ${ }^{29}$. She interprets the last painting as meeting Orpheus with Kerberos and Hades. Researcher suggests that the Phersu game is a possible parody of this core Orphic myth. We do not agree with this interpretation. The fact that cleaning of the vase some 50 years ago - hitherto unnoticed by scholarship - revealed Cerberus to be a regular single-headed $\operatorname{dog}^{30}$. Two additional heads were added during nineteenth-century 'restoration' in the accomplished early nineteenth-century Neapolitan restorers' workshops headed by Raffaele Gargiulo ${ }^{31}$. A new reading of the scene identifies it as the dialogue between Amphion and Zethos, a key episode in Euripides' play Antiope that is also referred to in Plato's Gorgias as emblematic of the rival concepts of the 'active' and the 'contemplative' life ${ }^{32}$.

S. A. Yatsemirsky believes that a comparison $\varphi$ ersu with $\varphi$ ersipnei does not have any foundation ${ }^{33}$. Connection of addressed in a mask character with the goddess of the underworld, a sin Greek and Etruscan appearance, in his opinion, is not confirmed by anything. The researcher postulates the existence of the Tyrsenian group of languages

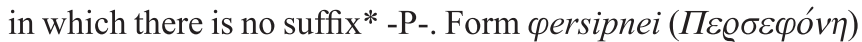
reminds him the transliteration of foreign-language names like 'E $\lambda$ ćv $^{\prime}$ elinai $^{34}$. It is Minoan theonym in this case, where the transition of $p$ to $\varphi$ is exposed not only to the peculiarities of Etruscan, but also related to it the Minoan language ${ }^{35}$.

Summarizing the above-mentioned, it is necessary to mark out the following versions. Phersu game is either the prototype of gladiatorial games or prototype of venatio, or the oldest version of the commedia dell'arte, or a theatrical performance of the last deed of Hercules, or dramatization of the similar Etruscan myth, or just a scene of the funeral ritual in the form of human sacrifice, or, finally, the absence any special cult game associated with Hades.

From our point of view, the interpretation of this painting should be searched at the intersection of several

concepts. Therefore, the aim of the work is the exarticulation in each of them the most significant, that what is possible to combine in a consistent hypothesis. In addition, it is important to find out where from gladiatorial games were: from Etruria, or from Campania.

First of all, the argument where gladiatorial games began should be solved after carefully reading of our sources. Athenaeus $\left(2^{\text {nd }}-3^{\text {rd }}\right.$ c. AD), whom the supporters of the origin

of gladiatorial games in Campania make reference to, did write about Campanians, combated at feasts (Athen. 4.39. p. $153 \mathrm{f})^{36}$. However, further he quoted more older $\left(1^{\text {st }}\right.$ c. BC) author Nicholaus of Damascus, who reported that the Romans borrowed the spectacle of gladiatorial combat at banquets of the Etruscans (Nic. Dam. Fr.84. FHG III). It should be noted that in this report funeral context inherent exactly to the

\footnotetext{
28 STODDART 2009, 147

29 AVRAMIDOU 2009, 74-76.

30 VILLING 2014, 64, fig. 2

31 VILLING 2014, 75-77.

32 VILLING 2014, 66-72.

3 YATSEMIRSKIY 2011, 218

4 YATSEMIRSKIY 2011, 167

35 YATSEMIRSKIY 2011, 135

36 See also: Sil. It. 11.48; Liv. 9.40.17.
}

Etruscans, is clearly discernable. It was lost by late gladiatura for the Etruscans conducted duel sat funeral feast (for example, the image of "Phersu game" on the tombs frescoes).

Tertullian quoted Timaeus, who informed about borrowing circuses from the Lydians, who in ancient times moved to Italy under the leadership of Tyrrenus (Tert. De spect. 5). Herodotus in details wrote about resettlement of the Lydians and he mentioned $\tau \alpha \dot{\alpha} \pi \alpha \imath \gamma v i \alpha$ (games) (Herod. 1.94). Under this word it should be understood an armed game or dance with a weapon. Dorian $\dot{\eta} \pi v \varrho \varrho i ́ \chi \eta$ (war dance) and dancing of Salii, according to one of the versions derived from the Etruscan city of Veii (Serv. Aen. 8. 285), as well as the Etruscan ritual dance with weapons during the sacrifice of a bull, pictured on the cover of the vase dated to $8^{\text {th }}$ century $\mathrm{BC}^{37}$ maybe regarded as the precursors of the armed struggle on graves.

About the appearance of Etruscan funerary games custom Herodotus reported specifically in another passage (Herod. 1.167). As if as after the Battle of Alalia (535 BC) the Tyrsenians from Caere executed captive Phocaeans, but when Apollo affected their city by epidemic, on the advice of the Pythia gymnastic competitions and chariot races in memory of the dead Greeks were organized ${ }^{38}$. Roman authors (Liv. 1.35.7.9; Dion. Hal. Ant. Rom. 3. 68) wrote that pugilists and charioteers were invited from Etruria to Rome at the Etruscan king Tarquinius. Stage games in Rome were also borrowed

from the Etruscans in $364 \mathrm{BC}^{39}$. It is known about the human sacrifices at the Etruscans in 358 BC (Liv. 7.15.11). However, Tertullian, criticizing "munus" (debt, duty, gladiatorial game), did not write about its Etruscan origin (Tert. De spect. 12).

One cannot be so categorical, saying that any image of Etruscan gladiatorial games was not found ${ }^{40}$. Since the last quarter of the 19 century they are known several images of Etruscan of the $3^{\text {rd }}-2^{\text {nd }}$ centuries BC (reliefs on funeral urns, terracotta statue, bronze statues from Clusium and Perusia), which shows the scenes of the armed men fighting against monster with a wolf's head and a human body ${ }^{41}$. J.-R. Jeannot has used in his work the images on urns from Perusia, area of Clusium and two from Volaterra the $2^{\text {nd }}$ century BC. They show scenes of a warrior fighting against a man with a dog's head, once a man with a dog's scalp on his head, once a dog held in a chain by a man in a pointed cap ${ }^{42}$. In this connection, we point out the fact about the image of the Etruscan god Aita (Eita) in a headdress of a wolf or a dog's scalp ${ }^{43}$ and recall the panic fear of Homer's epic heroes that their body without a proper burial will be given to the eating of $\operatorname{dogs}^{44}$. Probably, the Etruscans had similar notions.

Man-dog is signed by a famous Etruscan theonym calu. This gave to J.-R. Jannot the possibility to compare data of inscription with late ones from Orvieto tinia calusna (chthonic Zeus) (TLE 270) and on the sarcophagus from Tarquinii, which shows the position of the family of the

\footnotetext{
37 ETRUSCANS 1995, 17; RUPP 2007, Fig. III. 13

38 Caeretes had a treasure trove of Delphi (Strab. 5.2.3. C. 220).

39 Liv.7.2.4; Val. Max. 2.4.4; Plut. Quest. Rom.107. 289D; Tac. Ann. 14.21.

40 PAOLUCCI 2003, 11. GORONCHAROVSKIY 2009, 12; NOSOV 2010, 15

${ }^{41}$ ELLIOTT 1995, Fig. 3-6, 14; RUPP 2007, Fig. III. 8-12, 15-16.

2 JANNOT 1984, 52-53.

3 RUPP 2007, Fig. III. 1-2

Hom. Il. 22.334, 338-344, 348, 354; 24.211.554.
} 
deceased Aletnas munisvlet calusurasi $($ CIE $5819=$ TLE 172) and munisule $\theta$ calu (CIE $5820=$ TLE 173). The latest position was translated by A.I. Kharsekin, considering the first part of the phrase as borrowing from Latin munia (duties, authorities) ${ }^{45}$. However, it is also close to the name of gladiatorial games munus (pl. munera), the presence of Etruscan chthonic god indicates to the funerary character of "duty". Obviously, calu is a demon of death, but not Phersu. If we take munis as "pleasing", it can translate the whole phrase "pleasing to God Calu". Translation of "gifts to God Calu" in relation to such a noble deceased is inappropriate. As they are the epitaphs, it is possible that the inscriptions testify about funeral gladiatorial combat in honor of their characters, or the Aletnas themselves held positions of the organizers of these Games in their lifetime. It is possible that the games were held earlier and not only under Roman influence.

We know the bas-reliefs of urns with ashes of the second half of the 3th century BC from Perusia and Volaterra with pictures of gladiator fights of "Thracians" and "Gauls" (or the real prisoners of these people) ${ }^{46}$. Although, of course, these pictures are of the one-time with the appearance of gladiatorial combats in Rome in 264 BC (Liv. Per. 16; Val. Max., 2.4.7), and a hundred years younger than the famous frescoes of the tombs of Lucanian Paestum ${ }^{47}$, which are not far from the Campania.

It is known the fact, when the Emperor Constantine the Great issued in Berytus (now Beirut) the edict condemning "bloody performances"; but a decree to hold the games was specially promulgated for Hispellum (now Spello) for Umbria and Etruria priests 'qui aput Vulsinios Tusciae civitate(m) ludos sc(h)enicos et gladiatorum munus exhibeant' (who exhibit stage games and gladiatorial battle in Vulsinios civil community of Etruria) (CIL 11.5265).

Therefore, the fresco with Phersu (the $4^{\text {th }}$ century BC) organically fit into the sequence of the ancient dog's hunting of a man on the grave to organized fighting of two or more armed men, and can serve as a prototype of the gladiatorial games.

At the same time, the element «venatio» is not necessary to reject either ${ }^{48}$. Not only the presence of the dog, but the headwear of Phersu, clearly resembling pointed bashlyks of the Cimmerians on Etruscan vase of the $6^{\text {th }}$ century $\mathrm{BC}$ convinces us in it. On the sculptural decoration of pots type dinos form Capua dated to the end of the $6^{\text {th }}-5^{\text {th }}$ centuries $\mathrm{BC}$ (the period of Etruscan rule) there is a scene of equestrian and foot archers in peaked bent caps ${ }^{49}$ hunting with dogs. Evidently, caps of Cimmerians in the minds of the Etruscans became characteristic attribute of "wild hunt", and their dogs were identified with Cerberus of Hades, the entrance to which

was placed in Italy by mythographs ${ }^{50}$. Such costume was

${ }_{45}$ HARSEKIN/GELTSER 1965, 120.

46 TARNOWSKI 1987, 10; HÖFLING 1987, 14.

${ }_{47}$ NOSOV 2010, 15.

${ }_{48}$ Colorful paintings of chasing animals are submitted in Campana Tomb in Veii (now Veio), Tombs of the Hunter, Hunting and Fishing, Deer Hunting in Tarquinia.

${ }_{49}$ LOSEVA/SIDOROVA 1988, 250, fig. 256; 252, fig. 258; 253, fig. 259; 254, fig. 260.

${ }_{50}$ See n. 9-10; See also: Hom.Od. 11.14-19, where Cimmerians placed in the West; Schol. Hom. Od.11.14, where writing Kı $\mu \mu \varepsilon \varrho i ́ \omega v$ (Cimmerians) were corrected to $K \varepsilon \varrho \beta \varepsilon \varrho \varepsilon ́ \omega v$ (Cerberians); Ephorus put Cimmerians in Italy at Lake Avernus (apud Strab. 5.4.5. C. 244). generally typical for Etruscan actors. This is confirmed by a picture of the tomb of Monkey from Clusium, where actor, dressed like Phersu, plays the double flute ${ }^{51}$, as well as on the urns from the area of Perugia, Clusium and Volterra ${ }^{52}$.

As to the names Phersu and Phersipnay it is necessary

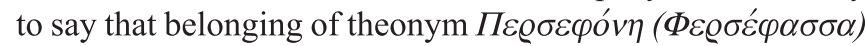
to Minoan language is known to modern linguists, but hardly ever the Greeks and the Etruscans in $6^{\text {th }}$ century BC knew about it. It is much easier to suggest that they due to old tradition adapted foreign word to particularity of their speech, giving to it "a folk etymology". In the Orphic hymn $\Phi \varepsilon \varrho \sigma \varepsilon \varphi o ́ v \eta$ it is interpreted as a "carrying killing" (from the words $\varphi \varepsilon ́ \varrho \omega$ 'I carry' and $\varphi o v \eta ́$ 'killing') (Orphic. 29.16). In "Lexicon" of Hesychius, in other words "bearing wealth"

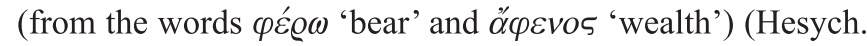
317). Probably the Etruscans offered their own or accepted the Greek interpretation. In fact, both persipnai (CIE 5091, Orvieto) and persipnei (CIE 5365, Tarquinia) have the same beginning $\varphi e r s-(\varphi \varepsilon ́ \varrho \omega)$ and a second part -ipnai (-ipnei), where the Greek $\varepsilon$ in the Etruscan word is replaced by $i^{53}$. Next comes the $p n$, where $o$ hides (in Etruscan $u$ corresponded to it), slipped as a result of such a feature of the Etruscan letters as loss of vowels in the second syllable. $\Phi$ is replaced by $p$ (the Etruscans did not distinguish them). Endings - $a i$-ei are put depending on form what dialect the Doric or Ionic of the Greek language the word is borrowed by the Etruscans.

Consequently, there is a component $\varphi \varepsilon ́ \varrho \omega$ (carry, manage, supervise) in the word $\varphi e r s u$. It allows us to connect Phersu with "gods puppeteers" Varuna, Zeus, Ogmios, Odin which according to the ancients notion governed people like puppets $^{54}$. Evidently, a fresco from the tomb of the Augurs reproduces a ritual where this performance is reproduced very

natural. Liberation from the rope sis interpreted in the spirit of Hellenistic magic as are lease of the soul from the "dungeon" of the body ${ }^{55}$.

On conclusion, it should be recognized that the ritual game Phersu existed and was a type of gladiatorial games and venatio. One can see a scene of the funeral rite, by artistic means of Etruscan art. This ritual is a substitutionary sacrifice and symbolizes man's struggle with the demon of death Calu, abductor of souls from the world of the living, guided by an invisible and disguised power, personified in the image of Phersu.

\section{REFERENCES:}

\section{ALTHEIM 1938}

Altheim, F.: A History of Roman Religion (London: Methuen) AVRAMIDOU 2009

Avramidou, A.: The Phersu game revisited, Etruscan Studies $12,73-86$

\section{BLUMENTHAL 1937}

von Blumenthal, A.: s. v. Persona, RE 19.37,1036

\section{BONFANTE/BONFANTE 2002}

Bonfante, G./ Bonfante, L.: Etruscan language. An introduction (Manchester: University Press)

${ }_{51}$ EMMANUEL-REBUFFAT 1983, 421, n. 4.

2 JANNOT 1984, 53.

So it was with the name of the beautiful Helena $E \lambda \varepsilon ́ v \alpha$ : elinei in Tarquinii, elinai in Volci, but elina in Praeneste (ThLE, p. 125).

54 Hom. Il. 8.19; Plato Leg. 644 e; Lucian. Herc. 3; ELIADE 1995, 152-158;

171-172, 178; SHIROKOVA 2002, 253-258; SHIROKOVA 2000, 317-323.

55 PETROV 2001, 51-53. 
BURIAN/MOUCHOVA 1966

Burian, J./ Mouchová, B.: Záhadní Etruskové (Praha: Mladá fronta)

DEEKE 1884

Deeke, W.: Etruskische Forschungen und Studien. H. 6. (Stuttgart: Verlag von Albert Heitz)

ELIADE 1995

Eliade, M.: Mefistofel şi androginul (București: Humanitas)

\section{ELLIOTT 1995}

Elliott, J.: The Etruscan Wolfman in Myth and Ritual, Etruscan Studies 2, 17-33

EMMANUEL-REBUFFAT 1983

Emmanuel-Rebuffat, D.: Le jeu du Phersu à Tarquinia: nouvelle interprétation, Comptes-rendus des séances de l'Académie des inscriptions et belles-lettres, 127.3, 421-438

\section{ETRUSCANS 1995}

Etruscans: Italy's lovers of life, ed. Dale Brown (London: Time Life Education)

FORSYTHE 2005

Forsythe, G. A.: Critical history of Early Rome. From prehistory to the First Punic War (Berkeley; Los Angeles; London: University of California Press)

FORTSON IV 2011

Fortson IV, B. W.: Indo-European language and culture. An introduction (Oxford: Wilay-Blackwell).

GORONCHAROVSKIY 2009

Goroncharovskiy, V. A.: Arena i krov: Rimskie gladiatoryi mezhdu zhiznyu i smertyu (Sankt-Peterburg.: Peterburgskoe vostokovedenie)

HARSEKIN/GELTSER 1965

Harsekin, A. I./ Geltser, M. L.: Novyie nadpisi iz Pirgi na finikiyskom i etrusskom yazyikah, VDI (3), 108-131

HEURGON 1961

Heurgon, J.: La Vie Quotidienne Chez Les Étrusques (Paris: Hachette)

HÖFLING 1987

Höfling, H.: Römer, Sklaven, Gladiatoren. Spartakus vor den Toren Roms (Gernsbach: Casimir Katz Verlag)

HUS 1980

Hus, A.: Les Étrusques et leur destin (Paris: Picard)

JANNOT 1984

Jannot, J.-R.: Un avatar etrusque du mythe grec, Revue des Études Latines 62, 45-56

JANNOT 1993

Jannot, J.-R.: Phersu, Phersuna, Persona. A propos du masque étrusque. In J.-P. Thuillier (ed.) Spectacles et scéniques dans le monde étrusco-italique: actes de la table ronde, (Rome: Ecole française de Rome), 281-320

LOSEVA/SIDOROVA 1988

Loseva, N. M./Sidorova, N. A.: Iskusstvo Etrurii i Drevney Italii (Moscow: Iskusstvo)

MACNAMARA 1987

MacNamara, E.: Everyday Life of The Etruscans (New York: Dorset Press)

NAGOVITSYIN 2000

Nagovitsyin, A. E.: Mifologiya i religiya etruskov (Moscow: Refl-buk)

NEMIROVSKIY 1983

Nemirovskiy, A. I.: Etruski. Ot mifa k istorii (Moscow: Nau$\mathrm{ka})$

NEMIROVSKIY/ HARSEKIN 1969

Nemirovskiy, A. I./ Harsekin, A. I.: Etruski. Vvedenie v etruskologiyu (Voronezh: Izd-voVoronezh. un-ta)

NOSOV 2010

Nosov, K. S.: Gladiatoryi (Moscow: Eksmo)

PAOLUCCI 2003

Paolucci, F.: Gladiatori: i dannati dello spettacolo (Firenze: Giunti)

PETROV 2001

Petrov, A. V. «Osvobozhdenie ot okov»: k voprosu o tselyah magicheskih protsedur $\mathrm{v}$ ellinistichesko-rimskoy magii. In E. D. Frolov (ed.), Antichnoe obschestvo - IV: Vlast i obschestvo $v$ antichnosti: Tezisyi dokladov nauchnoy konferentsii, Sankt-Peterburg (Russian Federation), 5-7 Marth 2001 (Sankt-Peterburg: Izd-vo SPbGU), 51-53

POULSEN 1922

Poulsen, F.: Etruscan tomb paintings. Their subjects and significance (Oxford: Clarendon Press).

ROBERT 2004

Robert, J.-N.: Les Etrusques (Paris: Les Belles Lettres)

RUPP 2007

Rupp, Jr. W. L.: Shape of the Beast: The Theriomorphic and Therianthropic Deities and Demons of Ancient Italy (PhD diss. Florida State University)

SHIROKOVA 2000

Shirokova, N. S.: Kultura keltov i nordicheskaya traditsiya antichnosti (Sankt-Peterburg: Evraziya)

SHIROKOVA 2002

Shirokova, N. S.: Ogmiy - keltskiy bog «svyazyivatel». In E. D. Frolov (ed.), Mnemon. Issledovaniya i publikatsii po istorii antichnogo mira, (Sankt-Peterburg: Izd-vo SpbGU), 253-262

\section{SKUTSCH 1907}

Skutsch, Fr.: s. v. Etruskische Sprache, RE 6.11, 770-806

SEAPEK 1998

Słapek, D.: Bustuarius gladiator- mit pierwszego gladiatora, In L. Morawiecki (ed.), Graecorum et Romanorum memoria I, Res Historica 5, (Lublin: Wyd-wo Uniwersytetu Marii Curie-Skłodowskiej), 115-131

SOKOLOV 2002

Sokolov, G. I.: Iskusstvo etruskov (Moscow: Slovo)

STEINGRÄBER 2006

Steingräber, S.: Abundance of life. Etruscan wall painting: from the geometric period to the Hellenistic period (Los Angeles: J. Paul Getty Museum)

STODDART 2009

Stoddart, S.: Historical dictionary of the Etruscans (Lanham: The Scarecrow Press)

TARNOWSKI 1987

Tarnowski, W.: Gladiatoren (Nürnberg: Tessloff Verlag)

TIMOFEEVA 1980

Timofeeva, N. K.: Religiozno-mifologicheskaya kartina mira etruskov (Novosibirsk: Nauka)

VETTER 1938

Vetter, E.: s. v. Phersipnai, RE 19.38, 2057

Vetter, E.: s. v. Phersu, RE 19. 38, 2058

VILLE 1981

Ville, G.: La gladiatureen Occidentdes origines à lamort de Domitien (Roma: Ecole française de Rome)

VILLING 2014

Villing, A. : 'Dengerous perfection' and an old puzzle resolved : a 'new' Apulian krater inspired by Euripides'Antiope, Bulletin of the Insitute of Classical studies, 57.1, 61-78

YATSEMIRSKIY 2011

Yatsemirskiy, S. A.: Opyit sravnitelnogo opisaniya minoyskogo, etrusskogo i rodstvennyih im yazyikov (Moscow: Yazyiki slavyanskoy kulturyi) 